Zigigniew ZioŁo

Akademia Pedagogiczna, Kraków

\title{
Procesy kształtowania się światowych korporacji i ich wpływ na otoczenie
}

Postępujące procesy rozwoju społeczno-gospodarczego prowadzą do kształtowania nowej bazy ekonomicznej, którą tworzy gospodarka oparta na wiedzy (Kukliński 2001). Funkcję motoryczną w tym procesie pełnią duże korporacje międzynarodowe o znacznym kapitale, zarządzane przez wysoko kwalifikowane grupy menedżerskie, mające własne instytucje naukowe prowadzące badania podstawowe, badawczo-rozwojowe, a także edukacyjne, finansowe i prawne oraz różnorodne oddziały i filie. Spełniają one różne funkcje w złożonych procesach produkcyjnych wielu zakładów, rozmieszczonych w przestrzeni światowej na terenie wszystkich kontynentach. W zależności od uwarunkowań regionalnych korporacje różnicują światową przestrzeń przemysłową w zakresie:

- koncentracji siedzib zarządów (Domański 2006; Gierańczyk, Stańczyk 2003; Sala 2003; Zioło 2003, 2006),

- lokalizacji fabryk produkcyjnych, usługowych i różnego rodzaju oddziałów (Wajda 2003, 2006; Wajda Zoricic-Wołek 2003; Wajda, Zalewska 2003),

- wpływania na międzynarodowe uwarunkowania rozwoju przemysłu układów krajowych i regionalnych (Kitowski 2003; Tkocz 2003; Tkocz, Sobala 2006; Tobolska, Matykowski 2003) i przedsiębiorstw przemysłowych (Rachwał 2003, 2006; Reśko 2006; Wieloński 2003; Wieloński, Szmigiel 2006; Zioło 2003),

- pobudzania procesu napływu bezpośrednich inwestycji zagranicznych (Brezień 2006; Sala 2006; Gierańczyk 2006),

- wpływania na kształtowanie się różnych sektorów przemysłowych (Huculak 2006; Gierańczyk 2006; Szpytkowska 2006)

- powiązań eksportowych (Komornicki 2006).

W nawiązaniu do przedstawionych przesłanek w niniejszych rozważaniach zwrócona zostanie uwaga na funkcjonowanie i rozwój światowych korporacji. Zmierzać będziemy do wyjaśniania mechanizmów kształtowania się korporacji światowej oraz jej wpływu na otoczenie. Wydaje się, że zaproponowane podejście stwarza nowe pole dociekań teoretycznych i ukierunkowuje badania empiryczne. Poznanie tego mechanizmu jest niezbędne dla podejmowania decyzji w otoczeniu funkcjonowania światowych korporacji dotyczących strategicznych działań, mających na celu zintensyfikowanie rozwoju różnego typu przedsiębiorstw, sektorów gospodarki, a także różnej skali układów przestrzennych.

Wzrost potencjału ekonomicznego światowych korporacji oraz nasilające się między nimi powiązania sieciowe w przestrzeni światowej (np. produkcyjne, naukowo-techniczne, 
organizacyjno-decyzyjne, finansowo-kapitałowe, zaopatrzenia surowcowego, kooperacyjne, a także powiązania rynkowe, energetyczne) oraz fuzje i przejęcia, generują procesy globalizacji i nasilają związane z nimi procesy integracji europejskiej ${ }^{1}$.

Wstępnie należy przyjąć, że podstawowym celem działalności korporacji jest podnoszenie konkurencyjności własnych produktów, zwiększanie efektywności działalności, pogłębianie istniejących, a także opanowywanie nowych rynków, co prowadzi do maksymalizacji zysku. Oznacza to, że rozwój społeczno-gospodarczy związanych z nimi struktur regionalnych czy krajowych dokonuje się jako skutek rozwoju działalności korporacji w określonym miejscu przestrzeni społeczno-gospodarczej i kulturowej.

W przestrzeni światowej, w wyniku nasilającego się procesu koncentracji kapitału, kształtujące się korporacje odznaczają się coraz większym potencjałem ekonomicznym, który niekiedy znacznie przewyższa potencjał gospodarczy wielu krajów. Np. w 2005 r. najwyższą wartością rynkową cechował się General Electric (377,4 mld USD), a następnie Exxon Mobil (361,1 mld USD), Microsoft (245,6 mld USD), Citigroup (245,6 mld USD) i BP (236,2 mld USD), podczas gdy w tym czasie PKB Polski wynosiło 303,2 mld USD, Portugalii 183,1 mld USD, a Słowacji 47,5 mld USD

Korporacje światowe poszukują nowych miejsc efektywnej lokalizacji i często w zasadniczym stopniu dyktują warunki funkcjonowania swoich firm na terenie poszczególnych krajów i regionów. Dlatego to nie korporacje, ale różnej skali układy przestrzenne poprzez podnoszenie swojej atrakcyjności dla nowych lokalizacji działalności gospodarczej starają się stworzyć jak najkorzystniejsze warunki dla przyciagania na swój teren nowych formy działalności gospodarczej, a także zmierzają do pobudzania wewnętrznych czynników rozwojowych ${ }^{2}$.

\section{STRUKTURA KORPORACJI ŚWIATOWEJ}

Proces kształtowania się korporacji światowych stymulowany jest poprzez mechanizmy konkurencji dokonujące się na rynku globalnym³ ${ }^{3}$ W konsekwencji zachowanie się korporacji na konkurencyjnym rynku wymaga koordynowania działań wszystkich jej segmentów, które spełniają w jej strukturze określone funkcje. Podstawowym jej celem jest bowiem wypracowywanie określonych zysków, które są podstawą dalszej kapitalizacji i rozwoju działalności. Korporacja światowa jest bardzo złożoną strukturą organizacyjno-produkcyjna, w której poszczególne elementy spełniają różnorodne funkcje, a ich działania muszą być W odpowiedni sposób koordynowane (ryc. 1).

${ }^{1}$ W styczniu i lutym 2006 r. największą wartością przejęć charakteryzował się koncern E.ON, który przejął firmę Endesa o wartości transakcji 57,1 mld USD, Mittal Steel przejmujący Arcelor (23,7 mld USD), Sonae (przejmujący Portugal Telecom - 17,0 mld USD) i BNP Paribas (przejmujący BNL - 11,0 mld USD).

${ }^{2}$ Np. niemiecki koncern samochodowy Daimler rozważa budowę nowej fabryki produkcji Mercedesa w Europie Środkowej. Z rywalizacji o nową lokalizację odpadły już Węgry, Słowacja i Czechy. Obecnie rozważana jest budowa fabryki w Polsce (koło Wrocławia) i Rumunii (Cluj). Ważną rolę odgrywają tu koszty pracy. W Rumunii godzina pracy kosztuje 4 euro, w Polsce 7,5, a w Niemczech ok. 30.

${ }^{3}$ Przykładem jest walka konkurencyjna między firmą General Motors i Toyotą na światowym i amerykańskim rynku samochodowym. W 2007 r. Toyota sprzedała na światowym rynku 9,4 mln samochodów, a General Motors o blisko 3,5 tys. więcej, ale Toyota osiągnęła 13,7 mld USD zysku, a General Motors 12 mld USD strat. 


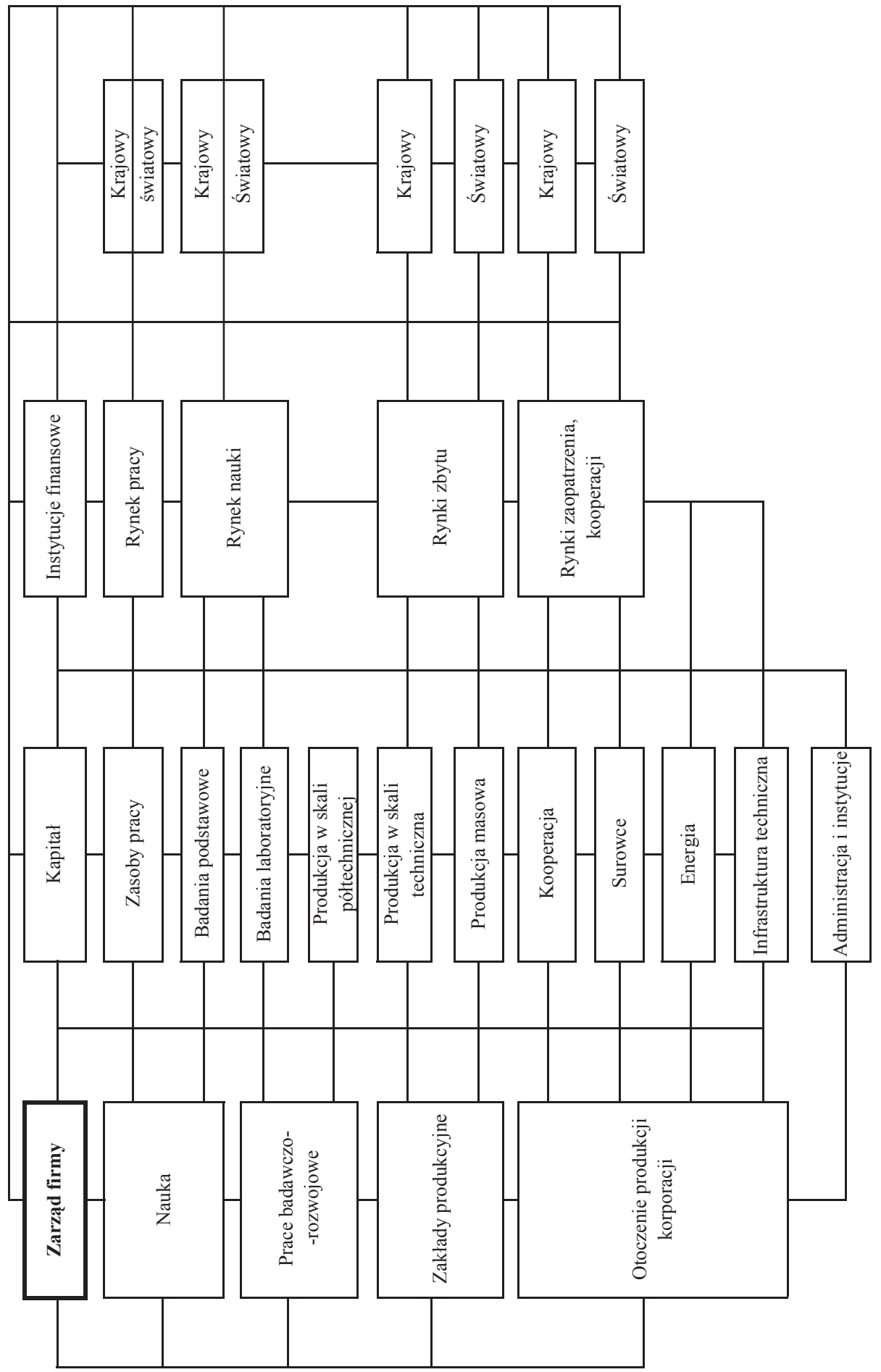

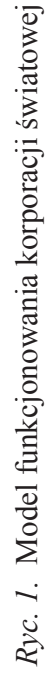

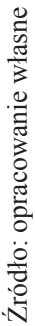


1. Podstawową rolę w strukturze korporacji odgrywa zarząd, który na podstawie odpowiednich przesłanek związanych z dążeniem do systematycznego podnoszenia konkurencyjności oferowanych produktów podejmuje określone decyzje doraźne ${ }^{4}$, a także decyzje strategiczne. Wynikają one z zmieniającej się sytuacji na rynku powstałych w wyniku zachowań konkurencyjnych firm oraz zasobów finansowych społeczeństwa i podmiotów gospodarczych.

W zarządzie koncentrują się funkcje informacyjne, które są podstawą podejmowania decyzji o zarządzaniu całością korporacji, a także jej segmentami, mających na celu zwiększenie efektywności ekonomicznej.

W działalności zarządu szczególnie ważną rolę odgrywają przesłanki służące do podejmowania decyzji w związku z:

- stopniem opanowania rynku oraz możliwościami jego pogłębiania i rozszerzania,

- obecną i przyszłą sytuacją finansowo-kapitałową,

- działaniami na rzecz restrukturyzacji technicznej, asortymentowej, organizacyjnej $\mathrm{i}$ in.,

- alokacją kapitału poprzez przenoszenie działalności produkcyjno-usługowej do nowych miejsc czy poszukiwanie miejsc nowych lokalizacji,

- osłabianiem działań konkurencyjnych innych firm, poprzez np. fuzje, przejęcia, konsolidację czy dążenia do eliminowania ich z rynku,

- dbaniem o systematyczne podnoszenie jakości oferowanych produktów i usług,

- wyznaczaniem kierunków rozwoju badań podstawowych i prac B+R, których wyniki można zastosować w produkcji, usługach, organizacji i zarządzaniu.

2. Podstawową rolę w strukturze korporacji odgrywa kapitał, wyrażony m.in. wartością rynkową korporacji, wartością majątku, wielkością zysku czy wielkością kapitału obrotowego. Wartość kapitału określa pozycję korporacji w gospodarce światowej, krajowej czy regionalnej. Zasoby kapitałowe pozwalają bowiem na podejmowanie różnych działań związanych np. z kierunkami prac inwestycyjnych, zakupami czy przejęciami innych firm, zmianami alokacji działalności produkcyjnej czy usługowej, podnoszeniem jakości kadry pracowniczej.

3. Bardzo ważnym segmentem korporacji jest jakość zasobów pracy, którą reprezentuje kadra zarządzająca i organizująca działalność oraz wykonująca określone zadania na różnicowanych hierarchicznie stanowiskach pracy. Szczególna rola przypada kadrze najwyżej kwalifikowanej, która podejmuje decyzje związane z wyznaczaniem strategicznych celów rozwoju korporacji, kierunków badań naukowych, wdrażaniem nowych rozwiązań technicznych, modernizacją produkcji i podnoszeniem jakości istniejących oraz wdrażaniem nowych produktów. Dlatego poddawana jest ona systematycznemu kształceniu, dokształcaniu oraz doskonaleniu zawodowemu i ogólnemu. Działania te realizowane są z uczelniami w określonym stopniu powiązanymi z korporacją, innymi instytucjami edukacyjnymi oraz jednostkami występującymi w strukturze korporacji.

${ }^{4}$ Decyzje doraźne dotyczą szybkich działań restrukturyzacyjnych wywołanych obniżaniem się pozycji konkurencyjnej firmy, najczęściej na początku dotyczą zwalniania pracowników czy przenoszenia zakładów produkcyjnych lub usługowych do nowych miejsc, najczęściej do krajów o niższych kosztach pracy. Np. Daimler Chrysler od 2005 r. zwolnił 8,5 tys. pracowników i zapowiada, że w ciągu trzech lat zwolni 6 tys. pracowników administracyjnych, co przyniesie oszczędności ok. 1 mld USD. Ford, który stracił drugą pozycję jako producent samochodów na rzecz Toyoty, do 2012 r. planuje zamknąc 14 swoich fabryk w USA i zmniejszyć moce produkcyjne o $25 \%$. W ciągu ostatnich 10 lat udział Forda na rynku USA zmniejszył się z 26,4\% do 17,4\% w 2005 r., a jego straty wynosiły 1,6 mld USD. 
4. Podstawowe znaczenie w zakresie podnoszenia nowoczesności produktów oferowanych przez korporację odgrywa nauka. Prowadzone badania podstawowe związane z profilem działalności korporacji służą do podejmowania prac badawczo-rozwojowych prowadzonych początkowo w laboratoriach, a następnie wdrażanych do produkcji w skali półtechnicznej ${ }^{5}$. Między badaniami podstawowymi, laboratoryjnymi i produkcją w skali półtechnicznej istnieją stałe przepływy informacji związane z podnoszeniem jakości opracowywanych rozwiązań technologicznych. Prace te wspierane są także wynikami badań innych ośrodków naukowych i naukowo-badawczych związanych z uczelniami czy różnego typu instytutami badawczymi, w większości wykonywanych na określone zapotrzebowanie korporacjí. L.C. Thurow (2006, s. 132) podkreśla, że badania i rozwój są to dwie różne rzeczy. Badania to dokonywanie przełomów i eksploracja nowych dziedzin, takich jak np. biotechnologia (pogłębianie wiedzy), natomiast rozwój to rozszerzanie wiedzy technologicznej w już istniejących dziedzinach (poszerzanie wiedzy). Pomiędzy badaniami a rozwojem znajduje się obszar badań stosowanych, w których do istniejących już podstaw naukowych różnych wynalazków trzeba dokonać przełomów w inżynierii czy konstrukcji, aby empirycznie zastosować to, co jest już znane w teorii naukowej?

Nowo opracowane produkty kierowane są do zakładów produkcyjnych rozmieszczonych w przestrzeni światowej ${ }^{8}$. Podejmują one produkcję masową gotowych wyrobów, produkcję określonych zespołów, podzespołów czy części zamiennych. Wraz z unowocześnianiem produktów finalnych dokonuje się w poszczególnych fabrykach częstej modernizacji parku maszynowego, a także prowadzi szkolenia pracowników, które są niezbędne dla wdrażania modernizowanych czy nowych produktów.

5. Ważną rolę w procesie funkcjonowania korporacji światowej odgrywają zróżnicowane funkcjonalnie segmenty otoczenia (powiązania kooperacyjne, zaopatrzenie surowcowe, rynki zbytu, zagospodarowanie infrastrukturalne, potencjalne zasoby pracy, instytucje B+R), które odznaczają się relacjami pasywnymi i aktywnymi z poszczególnymi segmentami korporacji. Relacje pasywne w odniesieniu do korporacji reprezentują przedsiębiorstwa odznaczające się powiązaniami w zakresie zaopatrzenia, np. w zakresie dostaw kooperacyjnych, zaopatrzenia w surowce, materiały i energię, a także sieciowe elementy infrastruktury technicznej i społecznej umożliwiającej kształtowania się korzystnych powiązań z otoczeniem.

${ }^{5} \mathrm{O}$ wadze nauki w działalności korporacji świadczą nakłady na prace badawczo-rozwojowe realizowane dla korporacji światowych. Np. w 2004 r. korporacja Daimler-Chrysler .przeznaczyła na badania naukowe 5,66 mld USD, Pfizer 5,65 mld USD, Ford Motor 5,44 mld USD, Toyota 5,42 mld USD, Siemens 5,07 mld USD, General Motors 4,78 mld USD, Microsoft 4,55 mld USD, podczas gdy Polska przeznaczyła na ten cel 1,14 mld USD, co jako korporacji dawałoby jej 64 miejsce (Monitoring Industrial Research: za „Gazeta Wyborcza” z 21 grudnia 2005).

${ }^{6}$ Jak podaje E. Wajda (2003) dla potrzeb Motoroli powstały w świecie uniwersytety w: Stanach Zjednoczonych (Arlington), Republice Południowej Afryki (Johannesburg), Japonii (Tokio) i Włoszech (Mediolan).

${ }^{7} \mathrm{~W}$ wyniku prowadzonych obecnie badań podstawowych i laboratoryjnych przyjmuje się, że w najbliższych latach konwencjonalną konstrukcję układów scalonych z krzemu zastapi nanotechnologia wykorzystująca do budowy urządzeń cząsteczki i pojedyncze atomy. Największe nadzieje wiąże się z nanorurkami o szerokości tysiące razy mniejszej niż średnica włosa, porównywalnymi z cząsteczkami białka. Prowadzi się także prace nad komputerami kwantowymi i biologicznymi.

${ }^{8}$ Np. 61 fabryk Toyoty zostało zlokalizowanych na terenie 26 krajów. Najwięcej na terenie Japonii (15 fabryk) i w Chinach (13), a następnie w Malezji i Tajlandii (po 3), w Kanadzie, Stanach Zjednoczonych, Filipinach, Wielkiej Brytanii i Polsce (po 2), a w pozostałych 17 krajach po jednej (Meksyk, Wenezuela, Kolumbia, Argentyna, Kenia, RPA, Pakistan, Bangladesz, Indie, Australia, Indonezja, Wietnam, Tajwan, Portugalia, Francja, Turcja, Rosja) (za: „Rzeczpospolita” z 5 października 2005). 
Ważną rolę w tym zakresie odgrywa także sprawnie funkcjonująca administracja i związana z nią jakość instrumentów prawnych oraz jakość różnorodnych instytucji finansowych, edukacyjnych i in. Tworzą one złożony system rynków zaopatrzenia w zakresie dostaw materiałów, surowców i półfabrykatów, a także rynku odpowiednich kadr pracowniczych ${ }^{9}$ i instytucji. Rynki te obejmują swoim zasięgiem różne skale układów przestrzennych - od skali lokalnej, poprzez skalę krajową, po skalę światową.

W zakresie powiązań aktywnych podstawowe znaczenie odgrywa otoczenie rynkowe, reprezentowane przez rynki zbytu, jakość rynków finansowych, rynków pracy oraz nauki. W zależności od miejsca lokalizacji siedziby zarządu korporacji czy jej zakładu produkcyjnego wyróżnia się, podobnie jak w zakresie powiązań pasywnych, rynki krajowe, międzynarodowe czy światowe. Szczególne znaczenie odgrywają rynki zbytu produktów gotowych. Mogą to być rynki dotychczasowe i nowe obszary rynkowe. Dotychczasowe rynki mogą być stabilne lub wykazywać tendencje dalszego pogłębiania się czy kurczenia. Nowe obszary rynkowe to takie, które do tej pory pozostawały niezagospodarowane lub obszary rynkowe innych producentów przejmowane przez daną korporację w wyniku nasilających się relacji konkurencyjnych. Na kształtowanie się obszarów rynkowych wpływają także występujące uwarunkowania związane głównie z zasobami finansowymi ludności, które generują potencjalne rozmiary popytu ${ }^{10}$.

\section{ZARYS FUNKCJONOWANIA KORPORACJI}

W świetle przedstawionych rozważań należy przyjąć, że zarządzanie korporacją światową wymaga precyzyjnej wiedzy dotyczącej funkcjonowania i przemian tej bardzo złożonej struktury kapitałowo-produkcyjnej, w której poszczególne elementy spełniają ściśle określone funkcje. Generalnie w procesie funkcjonowania korporacji międzynarodowej można wyróżnić cztery układy: zarząd korporacji, elementy związane z działalnością produkcyjną i usługową korporacji, elementy otoczenia bezpośrednio związane z działalnością korporacji i elementy otoczenia pośrednio związane z działalnością korporacji. W procesie funkcjonowania korporacji między poszczególnymi elementami strukturalnymi występują określone powiązania funkcjonalne (tab. 1).

Wśród elementów związanych z działalnością korporacji przykładowo wyróżniono: zarząd korporacji $\left(\mathrm{X}_{1}\right)$, zasoby pracy $\left(\mathrm{X}_{2}\right)$, kapitał (stały i obrotowy $\left.\mathrm{X}_{3}\right)$, sektor technologiczny $\left(\mathrm{X}_{4}\right)$, sektor prac $\mathrm{B}+\mathrm{R}\left(\mathrm{X}_{5}\right)$ oraz zakłady (produkcyjne, usługowe, przedstawicielstwa handlowe $\mathrm{i}$ in., $\mathrm{X}_{6}$ ). Relacje zachodzące między elementami strukturalnymi korporacji ilustruje macierz:

${ }^{9}$ Np. w 2001 r. do Stanów Zjednoczonych napłynęło 31,6 tys. wysokiej klasy specjalistów, w tym z Wielkiej Brytanii (13,3\%), Niemiec (13,3\%), Francji (13,2\%), Turcji (7,3\%), Włoch (4,7\%), a z Polski (3,1\%).

${ }^{10}$ Przejawem tego jest bardzo zróżnicowana światowa przestrzeń gospodarcza dla napływu bezpośrednich inwestycji zagranicznych. W 2004 r. najbardziej atrakcyjne dla napływu kapitału były kraje rozwinięte, których udział w ogólnych inwestycjach (612 mld USD) wynosił 52,4\%, następnie kraje rozwijające się - 41,7\%, a na kraje Europy Środkowej i Wschodniej (w tym Polski) przypadało tylko 5,9\% - UNCTAD (za: „Gazeta Wyborcza” z 14 styczna 2005). 


$$
\left[\begin{array}{l}
x_{11}^{x}, x_{12}^{x}, x_{13}^{x}, \ldots, x_{1 n} x \\
x_{21}^{x}, x_{22}^{x}, x_{23}^{x}, \ldots, x_{2 n}^{x} \\
x_{31}^{x}, x_{31}^{x}, x_{33}^{x}, \ldots, x_{3 n}^{x} \\
x_{n 1}^{x}, x_{n 2}^{x}, x_{n 3}^{x}, \ldots, x_{n n}^{x}
\end{array}\right]=x_{i j}^{x} \quad(\mathrm{i}=\mathrm{j}=1, \mathrm{n})
$$

W macierzy określającej relacje wewnątrz korporacji wyróżniają się trzy typy relacji: występujące w strukturze poszczególnych elementów oraz relacje aktywne i relacje pasywne zachodzące między nimi.

Pierwszy typ opisuje relacje wewnętrzne występujące w strukturze poszczególnych elementów, a to w strukturze:

$\begin{array}{ll}\text { zarządu }\left(\mathrm{X}_{1}\right) \text { korporacji } & {\left[\mathrm{x}^{\mathrm{x}}{ }_{11}\right],} \\ \text { zasobów pracy }\left(\mathrm{X}_{2}\right), & {\left[\mathrm{x}^{\mathrm{x}}{ }_{22}\right],} \\ \text { kapitału }\left(\mathrm{X}_{3}\right) & {\left[\mathrm{x}^{\mathrm{x}}{ }_{33}\right],} \\ \text { technologii }\left(\mathrm{X}_{4}\right) & {\left[\mathrm{x}^{\mathrm{x}}{ }_{44}\right],} \\ \text { sektora prac } \mathrm{B}+\mathrm{R}\left(\mathrm{X}_{5}\right) & {\left[\mathrm{x}_{55}^{\mathrm{x}}\right],} \\ \text { zakładów }\left(\mathrm{X}_{6}\right) & {\left[\mathrm{X}^{\mathrm{x}}{ }_{66}\right] .}\end{array}$

Drugi typ, to relacje aktywne, które obrazują wiersze macierzy przedstawiające wpływ danego elementu na pozostałe elementy, np. wpływ:

$\begin{array}{ll}\text { zarządu }\left(\mathrm{X}_{1}\right) \text { na zasoby pracy }\left(\mathrm{X}_{2}\right) & {\left[\mathrm{x}^{\mathrm{x}}{ }_{12}\right]} \\ \text { zarządu na }\left(\mathrm{X}_{1}\right) \text { na sektor } \mathrm{B}+\mathrm{R}\left(\mathrm{X}_{5}\right), & {\left[\mathrm{x}^{\mathrm{x}}{ }_{15}\right],} \\ \text { zarządu }\left(\mathrm{X}_{1}\right) \text { na zakłady }\left(\mathrm{X}_{6}\right) & {\left[\mathrm{x}^{\mathrm{x}}{ }_{16}\right] .}\end{array}$

Trzeci typ, to relacje pasywne, które opisują kolumny przedstawiające wpływ na dany element pozostałych elementów, np.

wpływ na zarząd $\left(\mathrm{X}_{1}\right)$ :

$\begin{array}{ll}\text { zasobów pracy }\left(\mathrm{X}_{2}\right), & {\left[\mathrm{x}^{\mathrm{x}}{ }_{21}\right],} \\ \text { kapitału }\left(\mathrm{X}_{3}\right) & {\left[\mathrm{x}^{\mathrm{x}}{ }_{31}\right],} \\ \text { technologii }\left(\mathrm{X}_{4}\right) & {\left[\mathrm{x}^{\mathrm{x}}{ }_{41}\right],} \\ \text { sektora prac } \mathrm{B}+\mathrm{R}\left(\mathrm{X}_{5}\right) & {\left[\mathrm{x}^{\mathrm{x}}{ }_{51}\right]} \\ \text { zakładów }\left(\mathrm{X}_{6}\right) & {\left[\mathrm{X}^{\mathrm{x}}{ }_{61}\right],}\end{array}$

czy wpływ na zakłady przemysłowe $\left(\mathrm{X}_{6}\right)$ :

$\begin{array}{ll}\text { zarządu }\left(\mathrm{X}_{1}\right) & {\left[\mathrm{x}^{\mathrm{x}}{ }_{16}\right],} \\ \text { kapitału }\left(\mathrm{X}_{3}\right) & {\left[\mathrm{x}^{\mathrm{x}}{ }_{36}\right]} \\ \text { sektora prac } \mathrm{B}+\mathrm{R}\left(\mathrm{X}_{5}\right) & {\left[\mathrm{x}^{\mathrm{x}}{ }_{56}\right] .}\end{array}$

Przedstawione relacje odnoszą się do wewnętrznych powiązań występujących w strukturze korporacji. Znajomość ich stanowi podstawę do podejmowania określonych decyzji związanych z podnoszeniem jakości funkcjonowania, kierunków potencjalnych przemian oraz określania działań strategicznych. 
Tab. 1. Model funkcjonowania

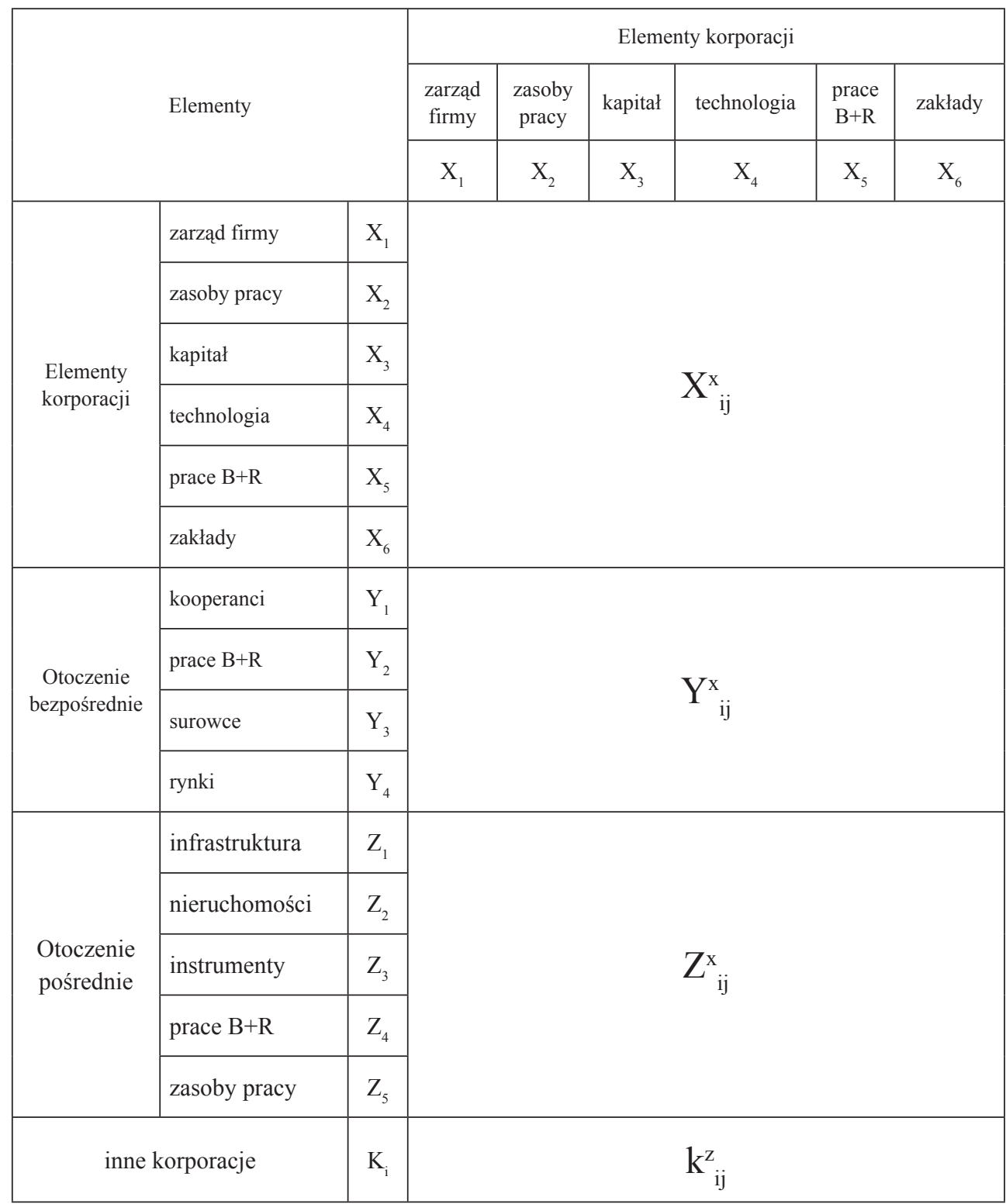

Źródło: opracowanie własne 
korporacji w otoczeniu

\begin{tabular}{|c|c|c|c|c|c|c|c|c|c|}
\hline \multicolumn{4}{|c|}{ Otoczenie bezpośrednie } & \multicolumn{5}{|c|}{ Otoczenie pośrednie } & \multirow{2}{*}{$\begin{array}{c}\text { Inne } \\
\text { korporacje }\end{array}$} \\
\hline kooperanci & $\begin{array}{c}\text { prace } \\
B+R\end{array}$ & surowce & rynki & $\begin{array}{l}\text { infra- } \\
\text { struktura }\end{array}$ & $\begin{array}{c}\text { nierucho- } \\
\text { mości }\end{array}$ & instrumenty & $\begin{array}{c}\text { prace } \\
B+R\end{array}$ & $\begin{array}{c}\text { zasoby } \\
\text { pracy }\end{array}$ & \\
\hline$Y_{1}$ & $\mathrm{Y}_{2}$ & $\mathrm{Y}_{3}$ & $\mathrm{Y}_{4}$ & $\mathrm{Z}_{1}$ & $\mathrm{Z}_{2}$ & $\mathrm{Z}_{3}$ & $Z_{4}$ & $Z_{5}$ & $\mathrm{~K}_{\mathrm{i}}$ \\
\hline \multicolumn{4}{|c|}{$\mathrm{X}^{\mathrm{y}}{ }_{\mathrm{ij}}$} & \multicolumn{5}{|c|}{$\mathrm{X}^{\mathrm{z}} \mathrm{ij}$} & $\mathrm{X}^{\mathrm{k}}{ }_{\mathrm{ij}}$ \\
\hline \multicolumn{4}{|c|}{$Y^{y}{ }_{i j}$} & \multicolumn{5}{|c|}{$Y_{i j}^{z}$} & $\mathrm{y}^{\mathrm{k}}{ }_{\mathrm{ij}}$ \\
\hline \multicolumn{4}{|c|}{$Z^{y}{ }_{i j}$} & \multicolumn{5}{|c|}{$Z^{z}{ }_{i j}$} & $\mathrm{Z}^{\mathrm{k}}{ }_{\mathrm{ij}}$ \\
\hline \multicolumn{4}{|c|}{$\mathrm{k}^{\mathrm{y}}{ }_{\mathrm{ij}}$} & \multicolumn{5}{|c|}{$\mathrm{k}^{\mathrm{z}}{ }_{\mathrm{ij}}$} & $\mathrm{k}^{\mathrm{k}}{ }_{\mathrm{ij}}$ \\
\hline
\end{tabular}




\section{RELACJE KORPORACJI Z OTOCZENIEM}

Dla funkcjonowania i rozwoju korporacji ważne znaczenie mają zachowania elementów bezpośredniego otoczenia związanych z działalnością korporacji.

1. Wśród elementów bezpośredniego otoczenia wyróżniono: firmy powiązane z korporacją poprzez:

- działalność kooperacyjną $\left(\mathrm{Y}_{1}\right)$,

- prace $\mathrm{B}+\mathrm{R}\left(\mathrm{Y}_{2}\right)$,

- dostawy surowców materiałów i energii (Y3),

- rynki zbytu (rynki istniejące, nowe, potencjalne o zasięgu krajowym, międzynarodowym, kontynentalnym czy światowym) $\left(\mathrm{Y}_{4}\right)$.

Wzajemne relacje występujące między tymi elementami opisują relacje wewnątrz poszczególnych elementów oraz relacje aktywne i relacje pasywne zachodzące między nimi.

$$
\left[\begin{array}{l}
y_{11}^{y}, y_{12}^{y}, y_{13}^{y}, \ldots, y_{1 m}^{y} x \\
y_{21}^{y}, y_{22}^{y}, y_{23}^{y}, \ldots, y_{2 m}^{y} \\
y_{31}^{y}, y_{31}^{y}, y_{33}^{y}, \ldots, y_{3 m}^{y} \\
y_{m 1}^{y}, y_{m 2}^{y}, y_{m 3}^{y}, \ldots, y_{m m}^{y}
\end{array}\right]=y_{i j}^{y} \quad \quad \quad(\mathrm{i}=\mathrm{j}=1, \mathrm{~m})
$$

Relacje wewnętrzne występujące w strukturze poszczególnych elementów związanych z korporacją określono poprzez:

- działalność kooperacyjną $\left(\mathrm{Y}_{1}\right) \quad\left[\mathrm{y}_{11}^{\mathrm{y}}\right]$,

- prace $\mathrm{B}+\mathrm{R},\left(\mathrm{Y}_{2}\right) \quad\left[\mathrm{y}_{22}^{\mathrm{y}}{ }^{2}\right]$,

- dostawy surowców $\left(\mathrm{Y}_{3}\right) \quad\left[\mathrm{y}_{33}^{\mathrm{y}} \mathrm{C}\right.$

- rynki zbytu $\left(\mathrm{Y}_{4}\right) \quad\left[\mathrm{y}_{44}^{\mathrm{y}}\right]$.

Relacje aktywne przedstawiają wiersze, w których określono wpływ danego elementu na pozostałe elementy, np. wpływ:

- kooperantów $\left(\mathrm{Y}_{1}\right)$ na dostawców surowców $\left(\mathrm{Y}_{3}\right) \quad\left[\mathrm{y}_{13}^{\mathrm{y}}\right]$,

- kooperantów $\left(\mathrm{Y}_{1}\right)$ na rynki zbytu $\left(\mathrm{Y}_{4}\right) \quad\left[\mathrm{y}^{4}{ }_{14}\right]$.

Relacje pasywne przedstawiają kolumny, w których przedstawiono wpływ na dany element pozostałych elementów, np.

wpływ na dostawców surowców $\left(\mathrm{Y}_{3}\right)$ :

- działalności kooperacyjnej $\left(\mathrm{Y}_{1}\right) \quad\left[\mathrm{y}_{31}^{\mathrm{y}}\right]$,

- rynków zbytu $\left(\mathrm{Y}_{4}\right) \quad\left[\mathrm{y}_{34}^{\mathrm{y}}\right]$.

2. Na efektywność działalności korporacji czy jej zakładów poważny wpływ wywierają elementy pośredniego otoczenia. W procesie zarządzania korporacją poznanie tych relacji ma bardzo ważne znaczenie i służy podejmowaniu określonych decyzji w zakresie dążenia do poprawy tych elementów (np. zmiana ustawodawstwa, doinwestowanie układów regionalnych czy krajowych w zakresie infrastruktury, podniesienie jakości kształcenia), które mogą stanowić potencjalne możliwości rozwoju działalności (np. poprzez napływ kapitału, przejęć czy konsolidacji). 
Wśród elementów otoczenia pośrednio związanych z działalnością korporacji wyróżniono:

- zagospodarowanie w zakresie infrastruktury techniczno-ekonomicznej i społecznej $\left(Z_{1}\right)$,

- system podatkowy $\left(Z_{2}\right)$,

- jakość instrumentów bezpośredniego i pośredniego oddziaływania $\left(Z_{3}\right)$,

- firmy niezwiązane z pracami $\mathrm{B}+\mathrm{R} \mathrm{z}$ działalnością korporacji, które dopiero moga stwarzać możliwości takiej współpracy $\left(\mathrm{Z}_{4}\right)$,

- potencjalne zasoby pracy, ich jakość oraz możliwości wykorzystania przez korporację $\left(\mathrm{Z}_{5}\right)$.

- inne korporacje $\left(\mathrm{K}_{\mathrm{i}}\right)$

Wzajemne relacje występujące między wyróżnionymi elementami opisują powiązania występujące w strukturze wewnętrznej poszczególnych elementów oraz relacje aktywne i pasywne zachodzące między nimi.

$$
\left[\begin{array}{c}
z_{11}^{z}, z_{12}^{z}, z_{13}^{z}, \ldots, z_{1 k}^{z} \\
z_{21}^{z}, z_{22}^{z}, z_{23}^{z}, \ldots, z_{2 k}^{z} \\
z_{31}^{z}, z_{31}^{z}, z_{33}^{z}, \ldots, z_{3 k}^{z} \\
z_{k 1}^{z}, z_{k 2}^{z}, z_{k 3}^{z}, \ldots, z_{k k}^{z}
\end{array}\right]=z_{i j}^{z}
$$

Relacje wewnętrzne występujące w strukturze poszczególnych elementów otoczenia korporacji określane są poprzez:

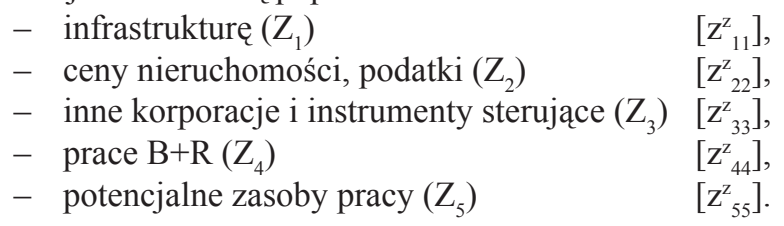

Relacje aktywne przedstawiają wiersze, w których określono wpływ danego elementu na pozostałe elementy, np. wpływ:

infrastruktury $\left(Z_{1}\right)$ na:

- ceny nieruchomości, podatki $\left(\mathrm{Z}_{2}\right) \quad\left[\mathrm{z}^{\mathrm{z}}{ }_{12}\right]$,

- instrumenty sterujące $\left(\mathrm{Z}_{3}\right) \quad\left[\mathrm{z}^{\mathrm{z}}{ }_{13}\right]$.

Relacje pasywne przedstawiają kolumny, w których określono wpływ na dany element pozostałych elementów, np.:

wpływ na infrastrukturę $\left(Z_{1}\right)$ :

- cen nieruchomości, podatków $\left(\mathrm{Z}_{2}\right) \quad\left[\mathrm{z}_{21}^{\mathrm{z}}\right]$,

- instrumentów sterujących $\left(Z_{3}\right) \quad\left[\mathrm{Z}^{\mathrm{z}}{ }_{31}\right]$,

- $\operatorname{prac} \mathrm{B}+\mathrm{R}\left(\mathrm{Z}_{4}\right) \quad\left[\mathrm{z}_{41}^{\mathrm{z}}\right]$.

3. Elementy korporacji w procesie przemian wpływają także na elementy otoczenia bezpośredniego i otoczenia pośredniego (por. tab. 1). 
Wpływ elementów korporacji $\left(\mathrm{X}_{\mathrm{i}}\right)$ na elementy otoczenia bezpośredniego $\left(\mathrm{Y}_{\mathrm{i}}\right)$ opisuje macierz [ $\mathrm{x}_{\mathrm{ij}}^{\mathrm{y}}$ ], wśród których wpływ zarządu $\left(\mathrm{x}_{1}\right)$ na prace $\mathrm{B}+\mathrm{R}\left(\mathrm{y}_{2}\right)$ określa macierz $\quad\left[\mathrm{x}^{\mathrm{y}}{ }_{12}\right]$, a wpływ kapitału $\left(\mathrm{x}_{3}\right)$ na rynki $\left(\mathrm{y}_{4}\right)$ macierz $\left[\mathrm{x}_{34}^{\mathrm{y}}\right]$.

Równocześnie elementy otoczenia bezpośredniego także oddziaływują na elementy korporacji, co określa macierz [ $\left.\mathrm{y}^{\mathrm{x}}{ }_{\mathrm{ij}}\right]$, np. wpływ rynków $\left(\mathrm{Y}_{4}\right)$ na zakłady $\left(\mathrm{x}_{6}\right)$ określa $\left[\mathrm{y}^{\mathrm{x}}{ }_{45}\right]$, a wpływ surowców na zakłady $\left[\mathrm{y}_{36}^{\mathrm{x}}\right]$. W procesie zarządzania korporacją poznanie tych relacji ma bardzo ważne znaczenie i służy podejmowaniu określonych decyzji związanych z koordynacją działań w strukturze korporacji z elementami bezpośredniego otoczenia.

W procesie przemian korporacja wykazuje określone relacje także z elementami otoczenia pośredniego. Oddziaływanie elementów korporacji na pośrednie elementy otoczenia określa macierz $\left[\mathrm{x}_{\mathrm{ij}}^{\mathrm{z}}\right.$ ], wśród których np.: wpływ kapitału $\left(\mathrm{X}_{3}\right)$ na nieruchomości $\left(\mathrm{Z}_{2}\right)$ wyraża macierz $\left[\mathrm{x}_{32}^{\mathrm{z}}\right]$, a wpływ technologii $\left(\mathrm{X}_{4}\right)$ na prace $\mathrm{B}+\mathrm{R}\left(\mathrm{z}_{4}\right)$ określa macierz $\left[\mathrm{x}^{\mathrm{z}}{ }_{44}\right]$. Odwrotne relacje odnoszące się do wpływu elementów otoczenia pośredniego na elementy korporacji określa macierz $\left[\mathrm{Z}_{\mathrm{ij}}^{\mathrm{x}}\right.$ ], gdzie wpływ zasobów pracy otoczenia $\left(\mathrm{x}_{5}\right)$ na zasoby pracy korporacji $\left(\mathrm{x}_{2}\right)$ określa macierz $\left[\mathrm{Z}_{52}^{\mathrm{x}}\right]$, a wpływ instrumentów $\left(\mathrm{z}_{3}\right)$ na zakłady $\left(\mathrm{X}_{6}\right)$ macierz $\left[\mathrm{Z}_{36}^{\mathrm{x}}\right]$.

4. W pracach analitycznych wykonywanych na rzecz korporacji równie ważne są informacje o relacjach zachodzących między elementami bezpośredniego i pośredniego otoczenia. Oddziaływanie elementów bezpośredniego otoczenia na elementy otoczenia pośredniego określa macierz $\left[\mathrm{Z}_{\mathrm{ij}}^{\mathrm{y}}\right.$ ], natomiast odwrotne relacje - wpływ elementów otoczenia pośredniego na elementy otoczenia bezpośredniego opisuje macierz $\left[\mathrm{y}^{\mathrm{z}}{ }_{\mathrm{ij}}\right]$. W otoczeniach tych kształtują się określone mechanizmy, np. rynkowe, na które w istotnym stopniu wpływają inne korporacje $\left(\mathrm{K}_{\mathrm{i}}\right)$. Mogą one stanowić bardzo ważną przesłankę dla podejmowania decyzji przez zarząd korporacji $\left(\mathrm{X}_{1}\right)$, którego podstawowym celem działania jest utrzymanie lub wzmocnienia swojej pozycji konkurencyjnej w stosunku do innych korporacji.

\section{RELACJE KONKURENCYJNE KORPORACJI}

W procesie funkcjonowania i rozwoju oraz budowie strategii przemian korporacji szczególnie ważna rola przypada analizie zachowań innych, zwłaszcza konkurencyjnych korporacji. Mechanizmy konkurencji między korporacjami mogą obejmować różnorodne sfery. Przyjmując kryterium jakościowe, można wyróżnić relacje konkurencyjne zachodzące między tego samego rodzajami korporacji, np. samochodowymi, informatycznymi lub różnorodnymi rodzajami. W obu wypadkach dotyczą one innych cech.

1. Korporacje tego samego typu konkurują w zasadzie o wszystko, by relatywnie utrzymać lub podnieść pozycję swoich produktów na rynku ${ }^{11}$. W tej sytuacji podstawowym celem działań jest zdobycie przewagi dla swoich wyrobów nad podobnymi lub o zbliżonych parametrach czy funkcjach użytkowych dostarczanych przez konkurencję. Podstawowym zagadnieniem jest więc podniesienie jakości oferowanych wyrobów, nawiązanie do zarysowujących się trendów mody oraz proponowanej możliwie niskiej ceny. Sprostanie tym wyzwaniom wymaga ciąłego unowocześniania systemów zarządzania, systematycznego podnoszenia poziomu kwalifikacji pracowniczych w drodze kształcenia, dokształcania i doskonalenia zawodowego, wprowadzania nowych technologii do procesów produkcyjnych i restrukturyzacji technicznej, organizacyjnej i wytwórczej zakładów produkcyjnych, a to wymaga przeznaczania znacznej ilości środków na badania podstawowe i rozwojowe.

\footnotetext{
${ }^{11} \mathrm{~Np}$. przytoczone relacje konkurencyjne między koncernami General Motors, Toyota i Ford Motor.
} 
Relacje konkurencyjne zaznaczają się także w otoczeniu bezpośrednim i dotyczą one kooperantów, zwiększania dostępności do wyników prac $\mathrm{B}+\mathrm{R}$, a równocześnie utrzymywania ich w tajemnicy, zapewnienia źródła zaopatrzenia surowcowego oraz dbałość o istniejące i perspektywiczne rynki.

Podobne relacje konkurencyjne zaznaczają się w otoczeniu pośrednim, chodzi tu o dostęp do infrastruktury, nieruchomości, zasobów pracy, a także o wzmocnienie roli instrumentów bezpośredniego i pośredniego oddziaływania ${ }^{12}$.

W relacjach konkurencyjnych szczególne znaczenie mają rozmiary kapitału i zasoby środków obrotowych, którymi dysponuje korporacja, a także jakość kadry zarządzającej. Odgrywają one szczególną rolę w zachowaniach konkurencyjnych, dzięki którym mogą prowadzić do upadku konkurencyjne korporacje o mniejszych zasobach czy możliwościach pozyskania kapitału i środków obrotowych na działalność produkcyjną. Z reguły pierwszym krokiem działań na rzecz oszczędności i restrukturyzacji korporacji jest zmniejszanie poziomu zatrudnienia.

2. Relacje konkurencyjne między korporacjami o odmiennym profilu działalności mogą obejmować wszystkie elementy otoczenia bezpośredniego i pośredniego lub tylko wybrane cechy. Szczególne znaczenie ma tu konkurencja na rynku nieruchomości, pozwalająca zwłaszcza na nowe lokalizacje i pozyskiwanie nowych zasobów pracy, umożliwiająca dostęp do elementów infrastruktury i kreowanie lub modernizację instrumentów sterujących procesami rozwoju.

Dlatego ważne miejsce w proponowanym modelu mają inne korporacje $\left(\mathrm{K}_{\mathrm{i}}\right)$. Dla zachowań konkurencyjnych danej korporacji jako szczególnie ważne należy uznać informacje o relacjach konkurencyjnych zachodzących między innymi korporacjami $\left[\mathrm{k}^{\mathrm{k}}{ }_{\mathrm{ij}}\right]$ oraz relacjach zachodzących w ich wewnętrznych strukturach i budowanych strategiach rozwoju, a także relacje zachodzące między elementami ich otoczenia.

Zagadnienia te odzwierciedlają poszczególne macierze, które określają:

wpływ innych korporacji $\left(\mathrm{K}_{\mathrm{i}}\right)$ na zachowania poszczególnych elementów:

- analizowanej korporacji $\left(\mathrm{X}_{\mathrm{i}}\right) \quad\left[\mathrm{k}_{\mathrm{ij}}^{\mathrm{z}}\right]$,

- otoczenia bezpośredniego $\left(\mathrm{Y}_{\mathrm{i}}\right) \quad\left[\mathrm{k}^{\mathrm{y}}{ }_{\mathrm{ij}}\right]$,

- otoczenia pośredniego $(\mathrm{Zi}) \quad\left[\mathrm{k}_{\mathrm{ij}}^{\mathrm{z}}\right]$.

Oddziaływanie analizowanej korporacji na inne korporacje $\left(\mathrm{K}_{\mathrm{i}}\right)$ poprzez:

- zachowania elementów $\left(\mathrm{X}_{\mathrm{i}}\right)$ danej korporacji $\quad\left[\mathrm{x}_{\mathrm{ij}}^{\mathrm{k}}\right]$,

- elementy otoczenia bezpośredniego $\left(\mathrm{Y}_{\mathrm{i}}\right) \quad\left[\mathrm{y}_{\mathrm{ij}}^{\mathrm{k}}\right]$,

- elementy otoczenia pośredniego (Zi)

$\left[\mathrm{z}^{\mathrm{k}}{ }_{\mathrm{ij}}\right]$.

Zarysowany model w generalnym zarysie prezentuje funkcjonowanie korporacji światowej. Wskazuje jednak na konieczność pogłębiania badań dotyczących struktury funkcjonalnej, która pod wpływem wielu uwarunkowań i czynników ulega ciągłym przemianom w zakresie wielkości i nasilenia powiązań aktywnych i pasywnych, dokonujących się w strukturze poszczególnych elementów korporacji, oraz relacjach między nimi oraz między otoczeniem, a także między elementami otoczenia korporacji. Oznacza to, że studiowanie przedstawionych relacji jest niezbędne dla podejmowania racjonalnych działań na rzecz podnoszenia pozycji konkurencyjnej danej korporacji.

Szczególnie ważnym problemem w procesie kształtowania się korporacji jest jej powiązanie z otoczeniem międzynarodowym (ryc. 2). Zakładamy, że poszczególne elementy

${ }^{12}$ Obserwujemy to zwłaszcza na terenie specjalnych stref ekonomicznych i w nowych centach rozwojowych, np. na terenach metropolii, obecnie głównie w Chinach czy Indiach. 

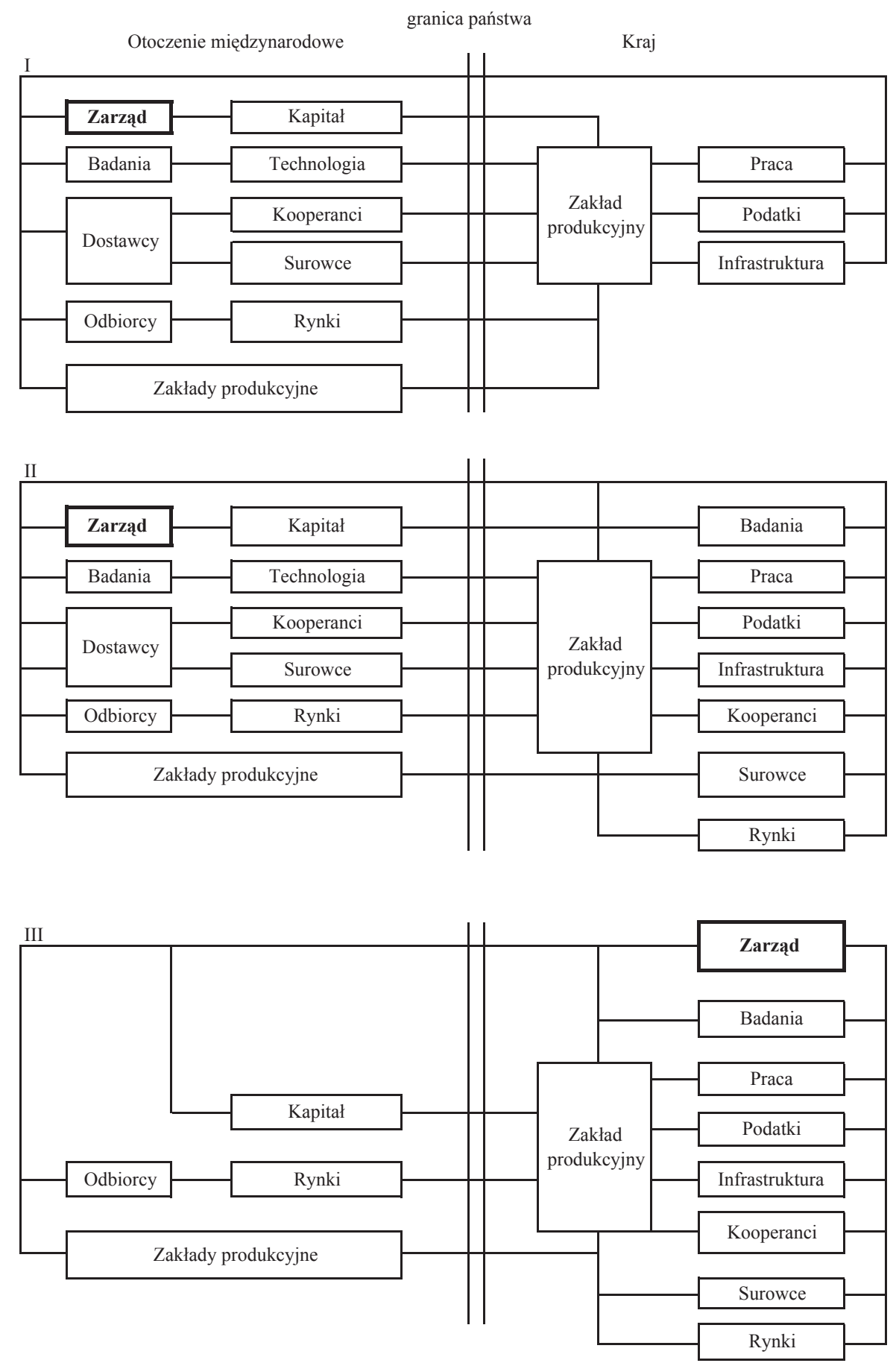

Ryc. 2. Typy powiązań przedsiębiorstw przemysłowych z otoczeniem międzynarodowym Źródło: opracowanie własne 
korporacji odznaczają się ciągłymi tendencjami do zwiększania swojego zysku, stąd cechują się dużą mobilnością przestrzenną w układach międzynarodowych. Korporacje wyszukują w przestrzeni geograficznej najbardziej atrakcyjne miejsca dla poprawy własnej kondycji finansowej. Należy zaznaczyć, iż przestrzeń geograficzna obejmuje niezwykle zróżnicowane elementy przyrodnicze, społeczne, ekonomiczne i kulturowe, które podnoszą lub obniżają pozycję konkurencyjną poszczególnych krajów, regionów czy układów lokalnych (Zioło 1999). Dlatego proces kształtowania korporacji jest bardzo złożony i przebiega z różnym natężeniem w czasie, czego przejawem jest m.in. wzrost produkcji ${ }^{13}$. Początkowo potencjalna korporacja odznacza się powiązaniami jej elementów z jednym krajem. Na obszarze danego kraju lokują się zarząd korporacji, zakłady produkcyjne, jednostki B+R, źródła kapitału, dostawcy (kooperanci, źródła zaopatrzenia w surowce i materiały), a także rynki zbytu.

W procesie wzrostu ekonomicznego następują przemiany przestrzenne działalności korporacji, wśród których umownie wyróżnić można trzy etapy.

Pierwszy charakteryzuje się rozprzestrzenianiem korporacji na inne kraje poprzez lokalizację na ich obszarach zakładów produkcyjnych czy usługowych. Powoduje to konieczność dostosowania lub budowania w danych układach regionalnych nowych elementów infrastruktury dostosowanych do potrzeb danego zakładu. Prace te realizowane są najczęściej ze środków publicznych. Korzyści układów regionalnych w tym etapie związane są z rozwojem nowych rynków pracy, co wpływa najczęściej na ograniczenie bezrobocia, napływ nowych zasobów pracy czy rozwój nowych kierunków kształcenia zawodowego. Prowadzi to także do zwiększenia strumieni finansowych płynących do gospodarstw domowych w formie zarobków oraz do jednostek władz samorządowych w formie podatków.

W wyniku stopniowego przenoszenia działalności korporacji na tereny innych krajów następuje przechodzenie korporacji do etapu drugiego ${ }^{14}$. Poza granicą kraju macierzystego lokalizowane są elementy związane z produkcją i usługami, badaniami naukowymi i $\mathrm{B}+\mathrm{R}$, nawiązywaniem kontaktów $\mathrm{z}$ istniejącymi firmami w zakresie relacji kooperacyjnych lub lokalizacją nowych zakładów spełniających te funkcje, wykorzystywaniem surowców, a także opanowywaniem stopniowo rynków zagranicznych i pogłębianiem już istniejących. $\mathrm{W}$ procesie tym utrwala się wewnętrzną strukturę korporacji oraz buduje nowe elementy na terenie innych krajów.

Korzyści wynikające z tych działań dla korporacji polegają na zwiększaniu jej pozycji na rynku, zwiększaniu zasobów kapitałowych, rozwoju i unowocześnianiu produkcji oraz zdobywaniu nowych rynków i zwiększaniu strumieni finansowych będących do dyspozycji zarządu.

Korzyści dla danych krajów i regionów, obok już wspomnianych, przejawiają się w przenoszeniu nowszych idei w zakresie zarządzania, produkcji i badań, do których wykorzystuje się lub przygotowuje kadrę pracowniczą, stwarzaniu możliwości powiązań kooperacyjnych z istniejącymi zakładami, wykorzystaniu regionalnych czy krajowych zasobów surowcowych, uruchamianiu nowych jakościowo mechanizmów rynkowych, dostarczających nowych i konkurencyjnych produktów i usług.

${ }^{13} \mathrm{~Np}$. Toyota stopniowo zwiększała swoją produkcję z 1 mln samochodów w 1968 r. i 4 mln w 1987 r. do 8 mln.

${ }^{14} \mathrm{~Np}$. korporacja Volvo zamierza podjąć decyzję o koncentracji produkcji autobusów model $8700 \mathrm{w}$ swej fabryce we Wrocławiu i zamknąć podobną fabrykę w Tampere (Finlandia). Volvo jest jednym z największych światowych producentów autobusów, w Europie ma cztery fabryki w Turku, Tampere (Finlandia), Saeffle (Szwecja) i we Wrocławiu. 
Etap trzeci odznacza się dalszym rozwojem korporacji i przenoszeniem coraz większej liczby elementów na tereny coraz to nowych krajów. Końcowym działaniem korporacji jest zmiana siedziby zarządu lub przenoszenie jego filii ze znacznymi uprawnieniami decyzyjnymi. W głównym stopniu wpływają na to zasoby tanich i dobrze przygotowanych zasobów pracy, zagospodarowanie infrastrukturalne i in., które prowadzą do obniżenia kosztów produkcji. Tendencje te pojawiać się będą w wypadku Chin i Indii, które odznaczają się dużym przyśpieszeniem procesów rozwoju społeczno-gospodarczego.

W procesie kształtowania korporacji należy przyjąć, że podstawowym celem jej działalności jest podnoszenie konkurencyjności własnych produktów, zwiększanie efektywności działalności, opanowywanie i pogłębianie rynków, co z kolei warunkuje maksymalizację zysku.

Korporacje przenoszą zwykle poza kraj siedziby zarządu firmy wykorzystujące miejscowe zasoby zwykle tańszej siły roboczej, która wpływa na obniżanie kosztów pracy ${ }^{15}$. Stosunkowo niskie koszty pracy i znaczne zasoby wykwalifikowanej kadr wpłynęły również na lokalizację w Polsce wielu centrów usługowych wiodących korporacji światowych (tab. 2). Centra te związane są głównie z obsługą księgowo-finansową 23 firm (m.in. największa światowa korporacja General Electric, Citibank, Tchibo, Volvo), pracami badawczymi 19 firm (m.in. General Electric, IBM, Motorola, Simens), usługami informatycznymi 4 firm (m.in. IBM, Ericpol, Telecom) i obsługa zaplecza firm (ABN Amro, Phillips, Fiat). Najbardziej atrakcyjnymi miejscami lokalizacji centrów usługowych są krajowe metropolie, a wśród nich Kraków, na terenie którego zlokalizowano 14 centrów (w tym 9 księgowo-finansowych i 5 badawczych), Warszawa - 8 centrów, (w tym 5 badawczych), Łódź 9 centrów (w tym 4 księgowo-finansowe i 3 informatyczne) oraz Wrocław (6 centrów), a nadto Gdańsk, Częstochowa, Bielsko-Biała, Zielona Góra, Olsztyn i Elbląg.

Korzystne czynniki rozwoju działalności produkcyjnej w Polsce przejawiają się także rosnącym zainteresowaniem lokalizacjami fabryk korporacji Dalekiego Wschodu (tab. 3). Podstawowe znaczenie ma tu możliwość wejścia fabryk światowych korporacji na obszar Unii Europejskiej i jej rynki. Przewidywana wartość inwestycji wynosi 2, 4 mld USD, podczas gdy ich przychody w 2005 r. wynosiły 328,9 mld USD. Znaczna cześć ofert lokalizacyjnych pochodzi z Japonii (1,3 mld USD), Korei Płd. (0,7 mld USD) oraz Indii (90,4 mld USD) i związana jest z przemysłem samochodowym i elektronicznym. Nawiązują one do krajowych ośrodków przemysłowych, które często w przeszłości rozwijały na swoim terenie tego rodzaje produkcję (m.in. Kraków, Dąbrowa Górnicza, Sosnowiec, Kielce, Wałbrzych, Poznań).

Wydaje się, że zarysowany model funkcjonowania korporacji światowej w pewnym zakresie pozwala na usystematyzowanie dotychczasowych wyników badań, a także otwiera nowe pola dla analiz dotyczących badania nasilających się relacji oraz procesu przemian światowej przestrzeni dokonującej się pod ich wpływem. Nadto coraz lepsze zrozumienie procesów funkcjonowania światowych korporacji i ich przemian można wykorzystać dla kreowanie polityki rozwoju krajowych układów regionalnych.

${ }^{15}$ Koszty pracy w przestrzeni światowej odznaczają się bardzo dużym zróżnicowaniem i w 2003 r. wahały się od 0,39 USD za godzinę w Indonezji , 0,80 USD w Chinach i 1,12 w Indiach, 2,70 USD w Polsce do 21,86 USD w Stanach Zjednoczonych i 30,60 w Niemczech (BCG za: „Gazeta Wyborcza” z 23 czerwca 2004). 
Tab. 2. Lokalizacje centrów usługowych koncernów światowych w $2006 \mathrm{r}$.

\begin{tabular}{|c|c|c|c|c|}
\hline \multirow[b]{2}{*}{ Miasta } & \multicolumn{4}{|c|}{ Typy usług } \\
\hline & Badawcze & Ksieggowo-Finansowe & Informatyczne & $\begin{array}{c}\text { Obsługi } \\
\text { zaplecza firm }\end{array}$ \\
\hline Warszawa & $\begin{array}{c}\text { General Electric } \\
\text { IBM } \\
\text { Oracie } \\
\text { Samsung } \\
\text { SAS }\end{array}$ & Tchibo & IBM & ABN Amro \\
\hline Kraków & $\begin{array}{c}\text { ABB } \\
\text { Delphi } \\
\text { Motorola } \\
\text { Pliva } \\
\text { Sabre }\end{array}$ & $\begin{array}{c}\text { Ahold } \\
\text { Cap Gemini } \\
\text { Exult } \\
\text { Electrolux } \\
\text { IBM } \\
\text { Lufthansa } \\
\text { Hewitt } \\
\text { Philip Morris } \\
\text { Shell }\end{array}$ & & \\
\hline Łódź & BSH & $\begin{array}{c}\text { Accenture } \\
\text { Bayer } \\
\text { General Electric } \\
\text { Philips }\end{array}$ & $\begin{array}{c}\text { Accenture } \\
\text { Ericpol Telecom } \\
\text { Hewlett-Packard }\end{array}$ & Philips \\
\hline Wrocław & $\begin{array}{c}\text { Ramy } \\
\text { Cap Gemini } \\
\text { Siemens } \\
\text { Hewlett-Packard }\end{array}$ & $\begin{array}{c}\text { Hewlett-Packard } \\
\text { Volvo }\end{array}$ & & \\
\hline Poznań & Glaxo SmithKline & $\begin{array}{c}\text { Glaxo SmithKline } \\
\text { Arvato } \\
\text { Carlsberg } \\
\end{array}$ & & \\
\hline Gdańsk & $\begin{array}{c}\text { Lucent } \\
\text { Technologies }\end{array}$ & Lucent Technologies & & \\
\hline Częstochowa & TRW Automotive & & & \\
\hline Bielsko-Biała & & & & Fiat \\
\hline Bydgoszcz & Intel & & & \\
\hline Zielona Góra & & $\mathrm{ADB}$ & & \\
\hline Olsztyn & & Citibank & & \\
\hline Elbląg & & ALSTROM & & \\
\hline
\end{tabular}

Źródło: McKinsey, Andersen BC, „Gazeta Wyborcza” z 14 kwietnia 2006 


\begin{tabular}{|c|c|c|c|c|c|c|c|c|c|c|c|c|}
\hline 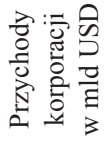 & $\stackrel{n}{n}$ & 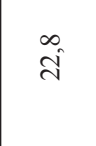 & $\hat{i n}$ & $\underset{\infty}{\Delta}$ & $\stackrel{\vec{n}}{n}$ & \multicolumn{3}{|c|}{$\overrightarrow{\infty_{i}}$} & $\stackrel{0}{\circ}$ & \multicolumn{2}{|c|}{$\stackrel{n}{\vec{n}}$} & $\begin{array}{l}\text { के } \\
\text { ते }\end{array}$ \\
\hline 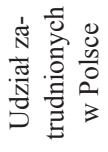 & $\stackrel{n}{=}$ & $\stackrel{0}{\rightarrow}$ & $\stackrel{0}{0}_{0}$ & $\overrightarrow{0}$ & $\hat{\infty}$ & \multicolumn{3}{|c|}{$\hat{n}$} & $\overbrace{0}^{2}$ & \multicolumn{2}{|c|}{. } & $\stackrel{\infty}{\sim^{\infty}}$ \\
\hline 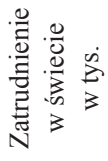 & $\begin{array}{l}0 \\
\text { ठ্. } \\
\text { in }\end{array}$ & $\begin{array}{l}\stackrel{0}{ \pm} \\
\stackrel{ \pm}{I}\end{array}$ & $\begin{array}{l}\stackrel{0}{0} \\
\stackrel{0}{1}\end{array}$ & 离 & $\hat{i}$ & \multicolumn{3}{|c|}{$\begin{array}{l}\stackrel{0}{ } \\
\text { ते }\end{array}$} & $\stackrel{\circ}{9}$ & \multicolumn{2}{|c|}{ 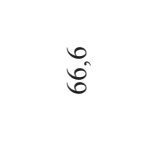 } & $\begin{array}{l}\circ \\
\text { ठ̊ } \\
0\end{array}$ \\
\hline 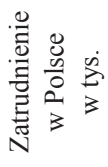 & $\begin{array}{l}\stackrel{0}{0} \\
\text { }\end{array}$ & $\stackrel{?}{=}$ & $\stackrel{0}{-}$ & $n$ & $\stackrel{\infty}{\rightarrow}$ & \multicolumn{3}{|c|}{ ते } & $\vec{m}$ & \multicolumn{2}{|c|}{. } & $\frac{r}{n}$ \\
\hline 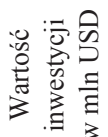 & $\stackrel{\sim}{\stackrel{2}{\sim}}$ & $\underset{\sim}{\sim}$ & 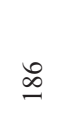 & t & $\stackrel{ }{=}$ & \multicolumn{3}{|c|}{ ฉి } & $\tilde{n}$ & \multicolumn{2}{|c|}{$\stackrel{\infty}{\varnothing}$} & $\underset{\sim}{\stackrel{f}{J}}$ \\
\hline 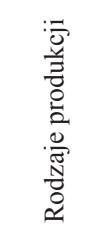 & 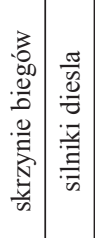 & 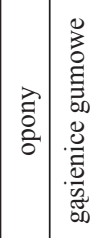 & 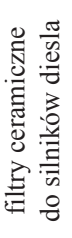 & 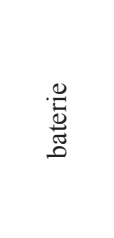 & 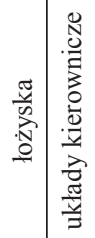 & \multicolumn{3}{|c|}{ 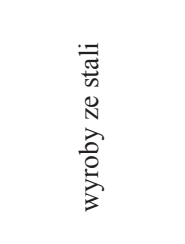 } & 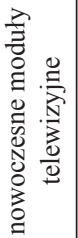 & 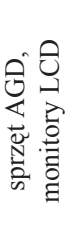 & 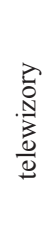 & \multirow{6}{*}{$\begin{array}{l}\text { 永 } \\
\frac{0}{80} \\
0\end{array}$} \\
\hline 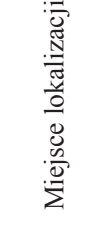 & 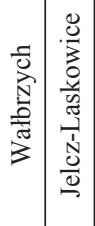 & 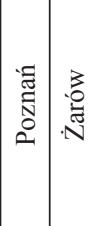 & . & 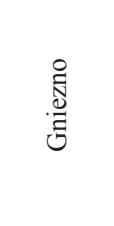 & 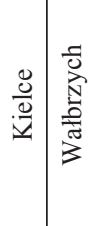 & 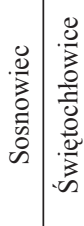 & 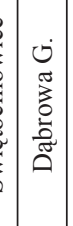 & 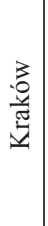 & 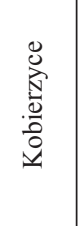 & 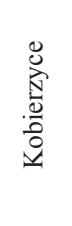 & $\frac{\tilde{c}}{\stackrel{\tilde{c}}{\Sigma}}$ & \\
\hline 西 & $\begin{array}{l}\text {. } \\
\text { : } \\
\text { : } \\
\text { : }\end{array}$ & 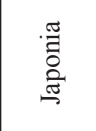 & 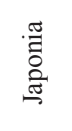 & 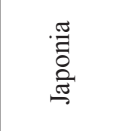 & $\begin{array}{l}\text { : } \\
\text { : } \\
\text { 产 }\end{array}$ & \multicolumn{3}{|c|}{$\stackrel{\overbrace{}}{\overparen{\Xi}}$} & 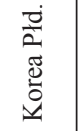 & \multicolumn{2}{|c|}{ 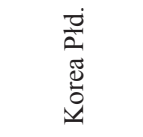 } & \\
\hline 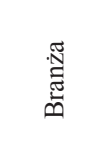 & 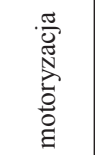 & 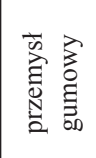 & 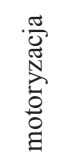 & 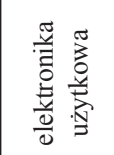 & 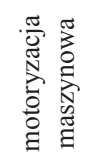 & \multicolumn{3}{|c|}{ 总 } & 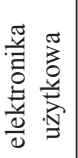 & \multicolumn{2}{|c|}{ 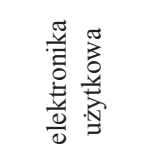 } & \\
\hline 毀 & $\begin{array}{l}\frac{\pi}{0} \\
\stackrel{0}{0} \\
\stackrel{0}{0}\end{array}$ & 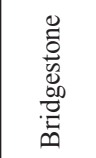 & 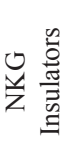 & 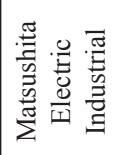 & $\frac{y}{\sum}$ & \multicolumn{3}{|c|}{ 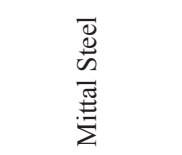 } & 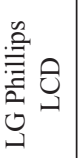 & \multicolumn{2}{|c|}{ பతG } & \\
\hline$\stackrel{\Omega}{~}$ & - & $N$ & $m$ & $\nabla$ & in & \multicolumn{3}{|c|}{0} & $r$ & \multicolumn{2}{|c|}{$\infty$} & \\
\hline
\end{tabular}




\section{Literatura}

Domański B., 2006, Polski przemyst na tle przemystu Europy Środkowej i Wschodniej, [w:] Międzynarodowe uwarunkowania rozwoju przemystu, red. Z. Zioło, T. Rachwał, Prace Komisji Geografii Przemysłu PTG, nr 8, Warszawa-Kraków, s. 27-46

Brezień P., 2006, Uwarunkowania bezpośrednich inwestycji zagranicznych i ich wpływ na umiędzynarodowienie działalności gospodarczej w województwo dolnoślqskim, [w:] Międzynarodowe uwarunkowania rozwoju przemystu, red. Z. Zioło, T. Rachwał, Prace Komisji Geografii Przemysłu PTG, nr 8, Warszawa-Kraków, s. 60-73

Huculak M. 2006, Procesy wspótkształtujace globalizację przemystu piwowarskiego Europy, [w:] Międzynarodowe uwarunkowania rozwoju przemystu, red. Z. Zioło, T. Rachwał, Prace Komisji Geografii Przemysłu PTG, nr 8, Warszawa-Kraków, s. 152-159

Gierańczyk W., 2003, Wybrane aspekty konkurencyjności polskiego przemystu w dobie globalnych wyzwań, [w:] Przemyst w procesie globalizacji, red. Z. Zioło, Z. Makieła, Prace Komisji Geografii Przemysłu PTG, nr 6, Warszawa-Kraków, s. 77-86

Gierańczyk W., 2006, Rola przedsiębiorstw w polskiej gospodarce $w$ okresie transformacji ustrojowej, [w:] Międzynarodowe uwarunkowania rozwoju przemystu, red. Z. Zioło, T. Rachwał, Prace Komisji Geografii Przemysłu PTG, nr 8, Warszawa-Kraków, s. 91-99

Gierańczyk W., Stańczyk A., 2003, Korporacje międzynarodowe w przestrzeni globalnej, [w:] Kształtowanie się struktur przemysłowych, red. Z. Zioło, Z. Makieła, Prace Komisji Geografii Przemysłu PTG, nr 5, Warszawa-Kraków, s. 73-83.

Kitowski J.(red.), 2003, Eastern Dimension of European Union, Geopolitical Studies, vol. 11, Polish Academy of Sciences, Institute of Geography and Spatial Organization, Warsaw

Komornicki T., 2006, Eksport w ujęciu regionalnym jako miernik rozwoju przemystu, [w:] Międzynarodowe uwarunkowania rozwoju przemystu, red. Z. Zioło, T. Rachwał, Prace Komisji Geografii Przemysłu PTG, nr 8, Warszawa-Kraków, s. 167-178

Kukliński (red.), 2001, Gospodarka oparta na wiedzy. Wyzwania dla Polski XXI wieku, Komitet Badań Naukowych, Warszawa

Paszkowski M., Luchter L., 2006, O problemach pomiaru efektów transformacji gospodarczej w porównaniach międzynarodowych, [w:] Międzynarodowe uwarunkowania rozwoju przemystu, red. Z. Zioło, T. Rachwał, Prace Komisji Geografii Przemysłu PTG, nr 8, Warszawa-Kraków, s. $100-108$

Rachwał T., 2003, Globalne uwarunkowania restrukturyzacji przedsiębiorstw Polski PoludniowoWschodniej, [w:] Przemyst w procesie globalizacji, red. Z. Zioło, Z. Makieła, Prace Komisji Geografii Przemysłu PTG, nr 6, Warszawa-Kraków, s. 129-138

Rachwał T., 2006, [w:] Restrukturyzacja technologiczna przedsiębiorstw przemystowych Polski Poludniowo-Wschodniej jako czynnik podnoszenia ich konkurencyjności na rynku międzynarodowym, [w:] Międzynarodowe uwarunkowania rozwoju przemystu, red. Z. Zioło, T. Rachwał, Prace Komisji Geografii Przemysłu PTG, nr 8, Warszawa-Kraków, s. 192-203

Reśko D., 2006, Funkcjonowanie matych i średnich przedsiębiorstw $w$ otoczeniu międzynarodowym, [w:] Międzynarodowe uwarunkowania rozwoju przemystu, red. Z. Zioło, T. Rachwał, Prace Komisji Geografii Przemysłu PTG, nr 8, Warszawa-Kraków, s. 115-126

Sala S., 2003, Wybrane cechy działalności korporacji transnarodowych i ich implikacje dla Polski, [w:] Przemyst w procesie globalizacji, red. Z. Zioło, Z. Makieła, Prace Komisji Geografii Przemysłu PTG, nr 6, Warszawa-Kraków, s. 101-107

Sala S., 2006, Bezpośrednie inwestycje zagraniczne a procesy globalizacji, [w:] Międzynarodowe uwarunkowania rozwoju przemystu, red. Z. Zioło, T. Rachwał, Prace Komisji Geografii Przemysłu PTG, nr 8, Warszawa-Kraków, s. 80-90 
Szpytkowska M., 2006, Rozwój sektora teleinformatycznego w Trójmieście jako przejaw procesów globalizacji, [w:] Międzynarodowe uwarunkowania rozwoju przemystu, red. Z. Zioło, T. Rachwał, Prace Komisji Geografii Przemysłu PTG, nr 8, Warszawa-Kraków, s. 160-166

Tkocz M., 2003, Przejawy procesu globalizacji w przemyśle województwa ślaskiego, [w:] Przemyst w procesie globalizacji, red. Z. Zioło, Z. Makieła, Prace Komisji Geografii Przemysłu PTG, nr 6, Warszawa-Kraków, s. 67-76

Tkocz M., Sobala O., 2006, Kapitał zagraniczny w przemianach gospodarczych tradycyjnego ośrodka przemystowego na przyktadzie Chorzowa, [w:] Międzynarodowe uwarunkowania rozwoju przemystu, red. Z. Zioło, T. Rachwał, Prace Komisji Geografii Przemysłu PTG, nr 8, WarszawaKraków, s. 74-79

Toboska A., Matykowski R., 2006, Działalność przemystowa w warunkach wzrastajacej internacjonalizacji i globalizacji na przykładzie wybranych produktów, [w:] Międzynarodowe uwarunkowania rozwoju przemystu, red. Z. Zioło, T. Rachwał, Prace Komisji Geografii Przemysłu PTG, nr 8, Warszawa-Kraków, s. 47-59.

Wajda E., 2003, Proces ksztaltowania się Motoroli jako firmy ponadnarodowej, [w:] Kształtowanie się struktur przemysłowych, red. Z. Zioło, Z. Makieła, Prace Komisji Geografii Przemysłu PTG, nr 5, Warszawa-Kraków, s. 85-114

Wajda E., 2006, Rozwój i struktura przestrzenna działalności Nokia w latach 1997-2003, [w:] Międzynarodowe uwarunkowania rozwoju przemystu, red. Z. Zioło, T. Rachwał, Prace Komisji Geografii Przemysłu PTG, nr 8, Warszawa-Kraków, s. 219-240

Wajda E., Zoricic-Wołek, 2003, Proces kształtowania się korporacji IBM, [w:] Przemyst w procesie globalizacji, red. Z. Zioło, Z. Makieła, Prace Komisji Geografii Przemysłu PTG, nr 6, WarszawaKraków, s. 117

Wajda E., Zalewska K., 2003, Struktura przestrzenno-organizacyjna General Motors, [w:] Przemyst w procesie globalizacji, red. Z. Zioło, Z. Makieła, Prace Komisji Geografii Przemysłu PTG, nr 6, Warszawa-Kraków, s. 119-127

Wieloński A., 2003, Przemyst Nowej Gospodarki, [w:] Przemyst w procesie globalizacji, red. Z. Zioło, Z. Makieła, Prace Komisji Geografii Przemysłu PTG, nr 6, Warszawa-Kraków, s. 21-25

Wieloński A., Szmigiel K., 2006, Europejskie uwarunkowania rozwoju sektora matych $i$ średnich przedsiębiorstw w Polsce, [w:] Międzynarodowe uwarunkowania rozwoju przemystu, red. Z. Zioło, T. Rachwał, Prace Komisji Geografii Przemysłu PTG, nr 8, Warszawa-Kraków, s. 109-114

Zioło Z., 1999, Model funkcjonowania przestrzeni geograficznej jako próba integracji badań geograficznych, [w:] Geografia na przełomie wieków - jedność w różnorodności, Wydział Geografii i Studiów Regionalnych Uniwersytetu Warszawskiego, Warszawa, s. 122-131

Zioło Z., 2003, Ksztattowanie się przedsiębiorstw przemystowych w procesie globalizacji, [w:] Przemyst w procesie globalizacji, red. Z. Zioło, Z. Makieła, Prace Komisji Geografii Przemysłu PTG, nr 6, Warszawa-Kraków, s. 9-19

Zioło Z., 2006, Zróżnicowanie światowej przestrzeni przemystowej w świetle koncentracji siedzib zarzadów wiodacych korporacji, [w:] Międzynarodowe uwarunkowania rozwoju przemystu, red. Z. Zioło, T. Rachwał, Prace Komisji Geografii Przemysłu PTG, nr 8, Warszawa-Kraków, s. 9-26 


\section{Global corporations' shaping processes and influence on their environment}

The chief role in the development of economy is played by the leading global corporations, characterized by great economic potential and network layout of the location of their branches. Basing on this, an attempt was made to build a model of a global corporation, including its structure and outline of functioning. Next, various types of its connection with its environment were determined. These relations were presented in a matrix and verified on the example of location of global corporations service centres and the location inquiries of Far East companies in Poland. 